\title{
Bioenergetic responses of Gammarus salinus and Mytilus edulis to oil and oil dispersants in a model ecosystem
}

\author{
Robert Scott Carr $^{1}$ and Olof Linden ${ }^{2}$ \\ ${ }^{1}$ Battelle New England Marine Research Laboratory, 397 Washington Street, Duxbury, Massachusetts, USA \\ 2 IVL Baltic Sea Laboratory, Utovagen 5, S-371 37 Karlskrona, Sweden
}

\begin{abstract}
As part of a multifaceted study to assess the impact of oil and oil dispersants on a model littoral ecosystem in the Baltic Sea, bioenergetic (O:N ratio) measurements were made for 2 of the predominant species, the mussel Mytilus edulis and the amphipod Gammarus salinus. In addition, ammonia excretion and respiration rate measurements for $G$. salinus and byssal thread production rates and spawning frequency observations for $M$. edulis were made. Four days after the start of the exposure, significant effects on byssal thread production rates and spawning frequency were observed for the oil/dispersant treatment. After $12 \mathrm{~d}$ the oil/dispersant group apparently had recovered whereas the oil-only group was exhibiting abnormal spawning behavior. No effects on ammonia excretion rates, respiration rates or $\mathrm{O}: \mathrm{N}$ rates were observed after $1 \mathrm{~d}$ for $G$. salinus. After $10 \mathrm{~d}$, however, highly significant differences were recorded between experimental groups and controls for all 3 parameters. While both oil and oil/dispersant treatments produced subtle physiological alterations in the animals investigated, the use of a chemical dispersant apparently resulted in a more rapid recovery of the species investigated than would have occurred if the oil had not been chemically dispersed.
\end{abstract}

\section{INTRODUCTION}

When an accidental discharge of oil occurs at sea there are usually several options available to the agency responsible for clean-up operations. If the spill is small and occurs in a protected area, it may be possible to enclose the spill with booms and to recover most of the oil. For larger spills this is not a realistic option. When large spills occur near coastal areas, the responsible agencies often are left with the choice of either allowing the oil to disperse and weather naturally or treating the spill with chemical dispersants, thereby minimizing the amount of material which might become stranded on the shore. The first generation of oil dispersants used in clean-up operations was far more toxic than the stranded oil (O'Sullivan and Richardson, 1967; Nelson-Smith, 1968). The latest generation of oil dispersants is much less toxic than its predecessors but the combination of oil and dispersant together can be more toxic than oil alone (Linden, 1975; Blackman et al., 1978; Carr, 1982).

The purpose of the present study was to assess the relative impact of chemically and physically dispersed oil on 2 common Baltic Sea invertebrate species utilizing a model ecosystem exposure regimen. Following the experimental oil spill, $O: N$ ratio measurements were made on the amphipod Gammarus salinus and the blue mussel Mytilus edulis from the different treatments in order to detect any bioenergetic alterations. The $\mathrm{O}: \mathrm{N}$ ratio, which is the ratio of oxygen consumed to nitrogen excreted in atomic equivalents, reflects the relative utilization of protein in energy metabolism. In addition to the bioenergetic measurements, observations on spawning behavior and byssal thread production were made for $M$. edulis. Changes in byssal thread production rates have been observed previously for $M$. edulis exposed to various petroleum hydrocarbons (Linden, 1977; Carr and Reish, 1978).

The study reported here is part of a larger study where the effects of oil and oil/dispersant were studied in mesoscale model ecosystems. The methods used and other biological effects are described elsewhere (Linden, in prep.; Rosemarin and Linden, in prep.). The results of the chemical analyses of water, oil and mussels are reported in Lindskog and Linden (in prep.). 


\section{MATERIALS AND METHODS}

In this experiment 6 circular pools were used. The pools had a surface area of $10.25 \mathrm{~m}^{2}$ and a volume of $7.5 \mathrm{~m}^{3}$. Each pool was provided with a continuous flow of seawater. The seawater intake was located at $7 \mathrm{~m}$ depth in the Denmark Bight, a bay of the Baltic Sea. The seawater was first pumped to a water reservoir and the flow into each pool was regulated by glass capillaries. The flow was adjusted to $2.8 \mathrm{l} \mathrm{min}^{-1}$ or a $50 \%$ replacement of the water in $24 \mathrm{~h}$. A surface paddle wheel (10 $\mathrm{cm}$ in diameter) provided a slight wave energy into the pools. The outlet from each pool was located about $20 \mathrm{~cm}$ above the bottom of the pool. It was covered by a mesh $(1 \times 1 \mathrm{~mm})$ to prevent macrofauna from escaping. Details of the experimental set-up have been published by Notini et al. (1977). The bladder wrack (Fucus vesiculosus) community, which was introduced into each pool about $8 \mathrm{wk}$ before the start of the exposure to oil and dispersant, contained all the normal floral and faunal components of an undisturbed community (Notini et al., 1977). The organisms had been collected from a shallow part of the Denmark Bight off the city of Karlskrona in the southern Baltic Sea. The salinity in the area is stable, around 7 to $8 \% \mathrm{~S}$, throughout the year. In the present experiment 2 replicate pools were exposed to oil alone, 2 replicates to oil and dispersant, and 2 served as controls. Ekofisk (North Sea) crude oil (154 ml) mixed with 1 l of seawater was shaken by hand for $2 \mathrm{~min}$ in a 21 glass bottle and then immediately added to the pools where oil alone was used. In the pools where oil and dispersant was used, the same amount of oil was used but $15.4 \mathrm{ml}$ of dispersant (Corexit 9550) was also added. Otherwise the same procedure was followed. The amount of oil added to each pool was equivalent to $20 \mathrm{mg} \mathrm{l}^{-1}$ assuming total mixture. The concentration of oil in water and in tissues of Mytilus edulis was measured using IR and $\mathrm{GC}$ techniques. For the IR analysis water samples were taken $1,6,12,24,63,93$, and $186 \mathrm{~h}$ after start of oil addition. The first 4 samples ( 1 to $24 \mathrm{~h}$ ) were collected in $2 \mathrm{l}$ glass bottles; the rest of the samples, using a continuous extraction technique (Lehtinen and Lehtinen, 1980) which extracted a volume of 30 to 501 . $\mathrm{CCl}_{4}$ was used as solvent. Details of the IR technique have been described by Rudling (1976). The GC analysis was carried out on a Carlo Erba Fractovap 4130 with a glass capillary column. Results of GC analyses are reported elsewhere (Lindskog and Linden, in prep.).

Gammarus salinus were collected from each pool ( 2 controls, 2 oil-only, 2 oil/dispersant) by removing a fucus plant in a bucket of water and gently rinsing the amphipods from the plant into the bucket. The amphipods were then transferred from the bucket to glass dishes for species and sex identification with a dissecting microscope. Only immature males were used in this study. After positive identification, 8 to 10 amphipods of approximately the same size $(10.6 \pm 3.5 \mathrm{mg})$ from each pool were individually placed in $70 \mathrm{ml}$ glass respirometry chambers containing filtered Baltic Sea water which was fully aerated. The amphipods were incubated for 16 to 18 h overnight with the respirometry chambers submerged in a water bath containing the same aerated Baltic Sea water. After incubation, a $1 \mathrm{ml}$ sample was obtained from each chamber by means of a syringe fitted into the top of the chamber, for determination of partial pressure of oxygen $\left(\mathrm{pO}_{2}\right)$, and an additional sample was placed in a screw-capped, plastic, liquid scintillation vial for ammonia analysis. After these samples were taken, the amphipods were thoroughly rinsed with double-distilled water and placed in tared aluminum weigh boats. After drying for $48 \mathrm{~h}$ at $60^{\circ} \mathrm{C}$, the specimens were allowed to air equilibrate for several hours before their dry weights were measured.

Mytilus edulis were suspended in the water column in each pool in mesh baskets. On Days 4 and 12 of the experiment, $\mathrm{O}: \mathrm{N}$ ratio and byssal thread production were measured on 7 mussels from each of the 6 pools. Before the mussels were placed into their individual 11 respirometry chambers, any external debris was removed from their valves and any byssal threads were carefully cut so as not to injure the byssal gland. $M$. edulis were also incubated overnight for $16 \mathrm{~h}$, submerged in a water bath containing air saturated Baltic Sea water. After incubation, samples were taken for $\mathrm{pO}_{2}$ and ammonia measurements, and the number of byssal threads produced was counted with the aid of an illuminated lens. During the $4 \mathrm{~d}$ experiment, the mussels were allowed to remain in their respirometry chambers, with the tops removed and submerged in the aerated water bath, for an additional $2 \mathrm{~d}$, at which time the number of byssal threads produced was again determined.

Following incubation, many mussels had spawned, presumably due to thermal stimulation (transfer from pools in late afternoon, when the temperature was near its daily maximum, to the water bath, where the temperature was maintained at the daily minimum temperature for incubation). Therefore, observations as to whether spawning occurred were made for each individual at both sampling periods.

Six control respirometry chambers without animals were run in conjunction with every experiment in order to account for any changes in $\mathrm{pO}_{2}$ or ammonia concentration due to microbial activity. The $\mathrm{pO}_{2}$ in water samples was determined with a Radiometer blood-gas analyzer employing the method of Laughlin et al. (1979). Ammonia determinations were made on replicate samples using the spectrophotometric phe- 
nolhypochlorite method of Solorzano (1969). The contribution of microbial activity to oxygen consumption and nitrogen excretion was very small in all experiments.

\section{RESULTS}

In this report only the IR analysis of the concentrations of oil in the water is presented. Full results of all chemical analyses made in this experiment are reported in Lindskog and Linden (in prep.). Analysis by IR (Table 1) showed that the highest concentrations were found $1 \mathrm{~h}$ after addition of oil, or of oil and

Table 1 . Concentration ( $\mathrm{mg} \mathrm{l}^{-1} \pm \mathrm{SD}$ ) of oil as determined by IR spectrophotometry during the first $8 \mathrm{~d}$ of the experiment

\begin{tabular}{|cccc|}
\hline $\begin{array}{c}\text { Time sample } \\
\text { taken (h) }\end{array}$ & $\begin{array}{c}\text { Con- } \\
\text { trol }\end{array}$ & $\begin{array}{c}\text { Oil/ } \\
\text { dispersant }\end{array}$ & Oil \\
\hline 1 & & $3.88 \pm 1.09$ & $0.83 \pm 0.44$ \\
6 & & $2.58 \pm 0.14$ & $0.53 \pm 0.15$ \\
12 & & $1.84 \pm 0.18$ & $0.64 \pm 0.35$ \\
24 & & $1.13 \pm 0.27$ & $0.70 \pm 0.04$ \\
63 & & $0.33 \pm 0.10$ & $0.10 \pm 0.09$ \\
93 & $0.07 \pm 0.04$ & $0.10 \pm 0.05$ & $0.03 \pm 0.00$ \\
186 & $0.11 \pm 0.01$ & $0.08 \pm 0.10$ \\
\hline
\end{tabular}

dispersant. This was also the first time samples were collected for analysis. In these samples around 4 ppm oil could be detected in pools where oil and dispersant was added. The corresponding figure for the pools where oil alone were added was slightly below $1 \mathrm{ppm}$ (Table 1). In pools where oil and dispersant were added, the oil content of the water dropped to background levels (approximately $0.07 \mathrm{mg} \mathrm{l}^{-1}$ ) after $93 \mathrm{~h}$, while the concentrations in the pools with oil alone reached the background after about $60 \mathrm{~h}$. No obvious mortality attributable to experimental exposures was observed at any time during this study.

$\mathrm{O}: \mathrm{N}$ ratio measurements for Mytilus edulis after 4 and $12 \mathrm{~d}$ of exposure are shown in Table 2. No significant differences were observed among any of the treatments or replicates within treatments for either experiment. Highly significant differences were observed for both byssal thread production and spawning behavior at both sampling periods (Table 3). After $4 \mathrm{~d}$ of exposure, the mean number of byssal threads produced after $16 \mathrm{~h}$ was 6.9 for controls, but only 1.1 for the oil/ dispersant group with $71 \%$ of the mussels in this treatment exhibiting no byssal thread production. After $68 \mathrm{~h}$ in clean water, byssal thread production was still significantly reduced compared to the control group. Of the control mussels $43 \%$ spawned during the $16 \mathrm{~h}$ incubation, whereas none of the oil/dispersant mussels spawned, and only $7 \%$ of the oil-only mussels spawned. After $12 \mathrm{~d}$, the byssal thread production rate of the oil/dispersant mussels had returned to normal, and $29 \%$ of the individuals had spawned, compared to $43 \%$ for the controls. None of the oil-only mussels, however, spawned during the $12 \mathrm{~d}$ post-spill incubation.

The results of the $\mathrm{O}: \mathrm{N}$ ratio, respiration and ammonia excretion rate measurements for Gammarus salinus after $1 \mathrm{~d}$ of exposure are given in Table 4. Although there were some apparent differences between replicates for the different treatments, there were no significant differences between any of the exposed amphipods, and the controls for any of the parameters when the treatment replicates were considered as a group.

At Day 10 after the start of the spill, highly significant differences were observed between the 2 experimental treatments and the control group for Gammarus salinus for all 3 parameters (Table 5). The $\mathrm{O}: \mathrm{N}$ ratio was lower and the respiration and ammonia excretion

Table 2. Mytilus edulis. $\mathrm{O}: \mathrm{N}$ ratios after 4 and $12 \mathrm{~d}$ of exposure

\begin{tabular}{|c|c|c|c|c|c|}
\hline \multirow[t]{2}{*}{ Treatment } & \multirow[t]{2}{*}{ Pool } & \multicolumn{2}{|c|}{$4 \mathrm{~d}\left(18^{\circ} \mathrm{C}\right)$} & \multicolumn{2}{|c|}{$12 \mathrm{~d}\left(15^{\circ} \mathrm{C}\right)$} \\
\hline & & $\mathrm{n}$ & $O: N \pm S E$ & $\mathrm{n}$ & $O: N \pm S E$ \\
\hline \multirow[t]{3}{*}{ Oil } & 5 & 7 & $27.9 \pm 5.6$ & 7 & $10.0 \pm 1.5$ \\
\hline & 6 & 7 & $24.8 \pm 3.3$ & 7 & $13.5 \pm 1.0$ \\
\hline & $5 \& 6$ & 14 & $26.4 \pm 3.1$ & 14 & $11.8 \pm 0.9$ \\
\hline \multirow[t]{3}{*}{ Oil \& dispersant } & 13 & 7 & $25.7 \pm 2.5$ & 7 & $7.8 \pm 0.6$ \\
\hline & 14 & 7 & $21.9 \pm 2.7$ & 7 & $13.1 \pm 3.2$ \\
\hline & $13 \& 14$ & 14 & $23.8 \pm 1.8$ & 14 & $10.4 \pm 1.7$ \\
\hline \multirow[t]{3}{*}{ Control } & 17 & 7 & $20.7 \pm 3.1$ & 7 & $11.3 \pm 1.8$ \\
\hline & 18 & 7 & $27.8 \pm 2.0$ & 7 & $14.1 \pm 2.1$ \\
\hline & $17 \& 18$ & 14 & $24.2 \pm 1.9$ & 14 & $12.8 \pm 1.4$ \\
\hline
\end{tabular}


Table 3. Mytilus edulis. Mean ( $\pm \mathrm{SE}, \mathrm{n}=7 /$ pool) byssal thread production and spawning percentage after 4 and $12 \mathrm{~d}$ of exposure. Asterisks: values significantly different than controls as determined by 1-tailed Mann-Whitney U-Test

\begin{tabular}{|c|c|c|c|c|c|c|c|}
\hline \multirow[b]{3}{*}{ Treatment } & \multirow[b]{3}{*}{ Pool } & \multicolumn{4}{|c|}{$4 \mathrm{~d}\left(18^{\circ} \mathrm{C}\right)$} & \multirow{2}{*}{\multicolumn{2}{|c|}{$\frac{12 \mathrm{~d}\left(15^{\circ} \mathrm{C}\right)}{16 \mathrm{~h} \text { incubation }}$}} \\
\hline & & \multicolumn{3}{|c|}{$16 \mathrm{~h}$ incubation } & \multirow{2}{*}{ 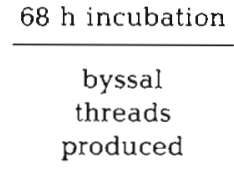 } & & \\
\hline & & $\begin{array}{l}\text { Byssal } \\
\text { threads } \\
\text { produced }\end{array}$ & $\begin{array}{l}\% \text { with no } \\
\text { byssal thread } \\
\text { production }\end{array}$ & $\%$ spawned & & $\begin{array}{c}\text { byssal } \\
\text { threads } \\
\text { produced }\end{array}$ & $\%$ spawned \\
\hline \multirow[t]{3}{*}{ Oil } & 5 & $8.6 \pm 2.5$ & 0 & 14 & $24.3 \pm 7.5$ & $10.7 \pm 1.5$ & 0 \\
\hline & 6 & $1.6 \pm 1.0$ & 57 & 0 & $9.1 \pm 1.3$ & $7.8 \pm 3.1$ & 0 \\
\hline & $5 \& 6$ & $5.1 \pm 1.6$ & 29 & 7 & $16.7 \pm 4.2$ & $9.2 \pm 1.7$ & $0^{\circ}$ \\
\hline Oil & 13 & $1.0 \pm 0.7$ & 71 & 0 & $6.9 \pm 2.8$ & $10.3 \pm 2.7$ & 0 \\
\hline$\&$ & 14 & $1.3 \pm 1.1$ & 71 & 0 & $11.1 \pm 3.2$ & $11.1 \pm 3.2$ & 57 \\
\hline dispersant & $13 \& 14$ & $1.1 \pm 0.6^{\cdots}$ & 71 & $0^{*}$ & $9.0 \pm 2.1^{\circ}$ & $10.7 \pm 2.0$ & 29 \\
\hline \multirow[t]{3}{*}{ Control } & 17 & $4.6 \pm 1.0$ & 0 & 43 & $12.4 \pm 3.3$ & $9.2 \pm 2.8$ & 29 \\
\hline & 18 & $9.1 \pm 3.1$ & 14 & 43 & $18.9 \pm 4.0$ & $8.3 \pm 1.5$ & 57 \\
\hline & $17 \& 18$ & $6.9 \pm 1.7$ & 7 & 43 & $15.6 \pm 2.6$ & $8.7 \pm 1.5$ & 43 \\
\hline
\end{tabular}

Table 4. Gammarus salinus. $\mathrm{O}: \mathrm{N}$ ratio, respiration and ammonia excretion rates $1 \mathrm{~d}$ after start of exposure

\begin{tabular}{|c|c|c|c|c|c|c|c|}
\hline Treatment & Pool & $\mathrm{n}$ & $O: N \pm S E$ & $\mathrm{n}$ & $\mathrm{ml} \mathrm{O} \mathrm{O}^{-1} \mathrm{~h}^{-1} \pm \mathrm{SE}$ & $\mathrm{n}$ & $\mu \mathrm{g} \mathrm{NH} \mathrm{N}_{4} \mathrm{~g}^{-1} \mathrm{~h}^{-1} \pm \mathrm{SE}$ \\
\hline \multirow[t]{3}{*}{ Oil } & 5 & 9 & $62.1 \pm 18.8$ & 8 & $1.03 \pm 0.09$ & 8 & $62.9 \pm 23.8$ \\
\hline & 6 & 10 & $26.3 \pm 3.6$ & 10 & $1.34 \pm 0.12$ & 10 & $98.5 \pm 16.5$ \\
\hline & $5 \& 6$ & 19 & $43.3 \pm 9.5$ & 18 & $1.20 \pm 0.09$ & 18 & $82.7 \pm 14.5$ \\
\hline Oil & 13 & 9 & $94.4 \pm 18.8$ & 10 & $0.95 \pm 0.08$ & 9 & $29.6 \pm 13.3$ \\
\hline$\&$ & 14 & 9 & $34.6 \pm 6.6$ & 9 & $1.23 \pm 0.10$ & 9 & $80.2 \pm 17.2$ \\
\hline dispersant & $13 \& 14$ & 18 & $64.5 \pm 11.3$ & 19 & $1.08 \pm 0.07$ & 18 & $54.9 \pm 13.0$ \\
\hline \multirow[t]{3}{*}{ Control } & 17 & 9 & $60.3 \pm 12.8$ & 10 & $1.11 \pm 0.09$ & 9 & $52.7 \pm 16.7$ \\
\hline & 18 & 9 & $25.8 \pm 3.3$ & 9 & $1.16 \pm 0.08$ & 9 & $88.3 \pm 20.7$ \\
\hline & $17 \& 18$ & 18 & $43.9 \pm 7.4$ & 9 & $1.13 \pm 0.06$ & 18 & $70.5 \pm 13.9$ \\
\hline
\end{tabular}

rates were higher in the exposed groups than in the controls. These responses are indicative of a higher metabolic rate and increased protein catabolism. These responses tended to be more pronounced for the oil-only group than for the oil/dispersant amphipods.

\section{DISCUSSION}

Bioenergetic measurements such as scope for growth, carbon flux and $\mathrm{O}$ : $\mathrm{N}$ ratios have been shown to be sensitive indices of stress for certain species at particular times in their reproductive or life cycles. Changes in the $\mathrm{O}: \mathrm{N}$ ratio for Mytilus edulis correlated well previously with alterations in scope for growth (Widdows, 1978), which has been shown to be the most useful physiological approach developed thus far for monitoring sublethal stress responses in the field (Gilfillan et al., 1976, 1977; Bayne et al., 1979). A decrease in the $\mathrm{O}: \mathrm{N}$ ratio has been reported for $M$. edulis during starvation (Gabbott and Bayne, 1973) and during sublethal pollutant exposure (Widdows, 1978). Alterations in the $\mathrm{O}: \mathrm{N}$ ratio have also been observed for larvae of the lobster Homarus americanus exposed to crude oil (Capuzzo and Lancaster, 1981), for Neomysis integer exposed to a light fuel oil (Laughlin and Linden, 1983) and for the grass shrimp Palaemonetes pugio exposed to zinc (McKenney, 1980). Effects of chronic low-level exposure to No. 2 fuel oil on respiration and ammonia excretion rates of zooplankton in the MERL microcosms were reported by Vargo (1981). The $\mathrm{O}: \mathrm{N}$ ratio for the community decreased at low oil concentrations (98 to $133 \mathrm{ppb}$ ) but increased at higher concentrations. Recently, a concentration-dependent alteration in the $\mathrm{O}: \mathrm{N}$ ratio of the opossum shrimp Mysidopsis bahia was correlated with reduced growth and reproductive suppression during a life cycle exposure to cadmium (Carr et al., 1984). 
Table 5. Gammarus salinus. O:N ratio, respiration and ammonia excretion rates $10 \mathrm{~d}$ after start of exposure. Asterisks: values significantly different than controls as determined by 1-tailed Mann-Whitney U-Test

\begin{tabular}{|c|c|c|c|c|c|c|c|}
\hline Treatment & Pool & $\mathrm{n}$ & $O: N \pm S E$ & $\mathrm{n}$ & $\mathrm{ml} \mathrm{O}_{2} \mathrm{~g}^{-1} \mathrm{~h}^{-1} \pm \mathrm{SE}$ & $\mathrm{n}$ & $\mu g \mathrm{NH}_{4} g^{-1} h^{-1} \pm \mathrm{SE}$ \\
\hline \multirow[t]{3}{*}{ Oil } & 5 & 8 & $52.9 \pm 5.7$ & 8 & $1.60 \pm 0.19$ & 9 & $51.3 \pm 8.2$ \\
\hline & 6 & 9 & $37.9 \pm 4.8$ & 9 & $1.50 \pm 0.10$ & 9 & $73.1 \pm 9.6$ \\
\hline & $5 \& 6$ & 17 & $45.0 \pm 3.9 \cdots$ & 17 & $1.54 \pm 0.10^{\cdots}$ & 18 & $62.2 \pm 6.9^{\cdots} \cdots$ \\
\hline Oil & 13 & 9 & $49.3 \pm 5.6$ & 9 & $1.50 \pm 0.07$ & 9 & $59.5 \pm 13.2$ \\
\hline$\&$ & 14 & 9 & $68.9 \pm 10.5$ & 7 & $1.56 \pm 0.18$ & 8 & $38.7 \pm 11.0$ \\
\hline dispersant & $13 \& 14$ & 18 & $59.1 \pm 6.1^{\circ}$ & 16 & $1.52 \pm 0.08^{\cdots} \cdots$ & 17 & $49.7 \pm 9.0^{\cdots}$ \\
\hline \multirow[t]{3}{*}{ Control } & 17 & 8 & $73.8 \pm 8.0$ & 8 & $1.26 \pm 0.11$ & 9 & $33.2 \pm 6.5$ \\
\hline & 18 & 9 & $105.0 \pm 14.5$ & 9 & $1.24 \pm 0.06$ & 9 & $26.2 \pm 9.2$ \\
\hline & $17 \& 18$ & 17 & $86.4 \pm 9.2$ & 17 & $1.25 \pm 0.06$ & 18 & $29.7 \pm 5.6$ \\
\hline
\end{tabular}

The direction of change of $\mathrm{O}: \mathrm{N}$ ratios for Mytilus edulis during stress depends on the season. In winter and spring when carbohydrates are low, stress results in reduced $\mathrm{O}: \mathrm{N}$ values, whereas in summer and autumn when carbohydrate reserves are high, the $\mathrm{O}: \mathrm{N}$ ratio increases during stress (Bayne, 1973). In marine environments, the $\mathrm{O}: \mathrm{N}$ ratio for $M$. edulis is normally between 20 and 60 in unstressed individuals depending on temperature and food availability (Widdows, 1978). In the present study $\mathrm{O}: \mathrm{N}$ values ranged between 28 and 8 . These relatively low values are indicative of a high rate of protein catabolism, which is usually indicative of a stressed condition. During late spring and early summer, after the spawning period, when tissue breakdown, regeneration and reorganization are occurring, $\mathrm{O}: \mathrm{N}$ ratios of $M$. edulis are lower than at any other time of the year (Widdows, 1978). The present study commenced in early June, which apparently was the spawning time for many of the $M$. edulis observed in this investigation (see Table 4). This may account for the unusually low $\mathrm{O}: \mathrm{N}$ ratios observed in this study. Adult $M$. edulis from the brackish Baltic Sea are much smaller than $M$. edulis from more marine environments. The low $\mathrm{O}$ : $\mathrm{N}$ values may alternatively reflect a continuously stressed condition for $M$. edulis in the Baltic Sea, which is near the lower salinity tolerance level of this euryhaline, cosmopolitan species.

That no alterations in the $\mathrm{O}: \mathrm{N}$ ratio were observed for Mytilus edulis during the first $12 \mathrm{~d}$ of the experiment may be due to the fact that $\mathrm{O}: \mathrm{N}$ levels were very low to begin with, or because the exposure was not severe enough in either concentration or duration to elicit a bioenergetic response. Recent studies suggest that the bioenergetic responses of $M$. edulis to petroleum hydrocarbons may not be as sensitive a physiological index for this species as was once thought (Stickle et al., 1984). Stickle exposed $M$. edulis to water-soluble fractions (WSFs) of Cook Inlet crude oil for $28 \mathrm{~d}$ in concentrations of up to $2.1 \mathrm{mg} \mathrm{l}^{-1}$ total aromatic hydrocarbons. While this exposure was considerably more severe than the exposure in the present study, the $O: N$ ratio did not vary as a function of exposure time or oil concentration, and ranged between 14 and 50 during their study with postspawned mussels (Stickle et al., 1984). It was concluded that any bioenergetic responses were primarily due to reduced feeding rates.

In the present study significant effects on byssal thread production and spawning behavior were observed in the different treatments for Mytilus edulis at both sampling periods. Based on byssal thread production and spawning behavior, oil/dispersant treatment produced a more dramatic effect than oil-only treatment after $4 \mathrm{~d}$. By Day 12, however, the mussels in the oil/dispersant treatment appeared to have recovered, while the oil-only group was still exhibiting abnormal spawning behavior. A reduction in byssal thread production has been observed previously for $M$. edulis exposed to WSFs of various types of crude and refined oils (Carr and Reish, 1978). In this study, the WSF of south Louisiana crude oil was more effective in its inhibitory influence on byssal thread production than were the two refined oils (No. 2 fuel oil and Stalube outboard motor oil) on a percent WSF basis. Other studies have shown the WSF of No. 2 fuel oil to be more toxic than south Louisiana crude oil on a percent WSF and total hydrocarbon basis for a variety of marine organisms (Anderson et al., 1974; Rossi et al., 1976; Carr and Reish, 1977). It appeared, therefore, that unlike most of the other marine organisms tested, $M$. edulis may be more susceptible to contamination by crude oil than by these refined oils.

Alterations in $\mathrm{O}: \mathrm{N}$ ratios for crustaceans exposed to crude oil have been observed previously. Larval lobsters, Homarus americanus, exposed to sublethal con- 
centrations of south Louisiana crude oil exhibited decreased respiration rates and reduced $\mathrm{O}: \mathrm{N}$ ratios during the first $3 \mathrm{~d}$ of exposure (Capuzzo and Lancaster, 1981). The changes observed in the protein : lipid ratio of the tissues of the oil-exposed and control lobster larvae support the contention that reduced $\mathrm{O}: \mathrm{N}$ ratios are indicative of increased dependence on protein catabolism.

Laughlin and Linden (1983) observed changes in respiration rates, ammonia excretion rates and $\mathrm{O}: \mathrm{N}$ ratios of adult mysid shrimp Neomysis integer exposed to WSFs of a light fuel oil under a variety of temperature and oil concentration combinations. During a $15 \mathrm{~d}$ experiment the ammonia excretion rates increased and the $\mathrm{O}: \mathrm{N}$ ratio decreased, whereas the opposite responses were observed initially during an acute exposure. The authors suggest that the changes observed in the ammonia excretion rates as a result of acute oil exposure were caused by an effect on ammonium transport functions of the gill membrane. In support of this hypothesis they cite a study by Heitz et al. (1974) which they claim rules out the possibility of any effects on intermediary metabolism because oil does not affect any enzyme systems responsible for ammonia production'. While the gill's ammonium transport function may be impaired during acute oil exposure, the study by Heitz et al. certainly does not provide an adequate explanation for this contention, and the results of other similar studies support the view that physiological stressors, be they environmental or pollutional, which produce bioenergetic responses characterized by increased ammonia excretion rates and decreased $\mathrm{O}: \mathrm{N}$ ratios, exert their primary effect through shifts in catabolic substrate utilization.

In the present study, no significant differences in the metabolic parameters or the $\mathrm{O}: \mathrm{N}$ ratios were observed for Gammarus salinus after $1 \mathrm{~d}$ of exposure among the treatments. By Day 10, however, significant metabolic responses occurred in control and experimental groups. G. salinus exposed to oil and oil/dispersant exhibited increased ammonia excretion and respiration rates, as well as decreased $\mathrm{O}: \mathrm{N}$ ratios compared to controls. We interpret these results as an indication of increased protein catabolism, relative to lipid and carbohydrate catabolism; if prolonged, this response is likely to result in decreased growth (Carr et al., 1984). These responses tended to be less pronounced for the oil/dispersant amphipods which were either less affected or recovering more rapidly than the oil-only individuals.

The results of these physiological studies suggest that the oil/dispersant treatment caused more pronounced effects initially but that the long-term effects persisted to a greater extent in the oil-only treatment. It seems likely that in the chemically dispersed oil treat- ments the water column concentration of petroleum hydrocarbons was increased initially, but the amount of persistent oil components adsorbed to particulates or adhering to hard substratum was reduced as compared to the treatments dispersed only by physical processes. Although both treatments produced sublethal physiological alterations in the animals investigated, it appears that for the conditions evaluated in this study, the use of a chemical dispersant resulted in a more rapid recovery of the physiological parameters measured than would have occurred if the oil had not been chemically dispersed.

Acknowledgements. This study was supported, in part, by a visiting research fellowship from the Swedish Environmental Research Institute (IVL) to R. S. Carr and by a Grant No. OCE 81-11949 from the National Science Foundation as part of the Pollutant Responses in Marine Animals (PRIMA) program. Erland Jacobsson provided expert technical assistance during this study. We gratefully acknowledge the editorial assistance of Marcia Carr.

\section{LITERATURE CITED}

Anderson, J. W., Neff, J. M., Cox, B. A., Tatem, H. E., Hightower, G. M. (1974). Characteristics of dispersions and water-soluble extracts of crude and refined oils and their toxicity to estuarine crustaceans and fish. Mar. Biol. 27 : $75-88$

Bayne, B. L. (1973). Physiological changes in Mytilus edulis L induced by temperature and nutritive stress. J. mar. biol Ass. U.K. 53: $39-58$

Bayne, B. L. (1978). Further studies on the effects of stress in the adult on the eggs of Mytilus edulis. J. mar. biol. Ass. U.K. 58: 825-841

Bayne, B. L., Moore, M. N., Widdows, J., Livingstone, D. R. Salkeld, P. (1979). Measurement of the responses of individuals to environmental stress and pollution: studies with bivalve molluscs. Phil. Trans. R. Soc. (B) 286: 563-581

Blackman, R. A. A., Franklin, F. L., Norton, M. G., Wilson, K. $W$. (1978). New procedures for the toxicity testing of oil slick dispersants in the United Kingdom. Mar. Pollut. Bull. 9: $234-238$

Capuzzo, J. M., Lancaster, B. A. (1981). The physiological effects of south Louisiana crude oil on larvae of the American lobster (Homarus americanus). In: Vernberg, F. J., Calabrese, A., Thurberg, F. P., Vernberg, W. B. (ed.) Biological monitoring of marine organisms. Academic Press, New York, p. 405-424

Carr, R. S. (1982). Toxicity of five oil dispersants to the sand shrimp Crangon septemspinosus and of various weathered stages of Brae crude oil to Mysidopsis bahia. Final Report submitted to Marathon Oil Company, Littleton, Colorado, USA, p. 1-9

Carr, R. S., Reish, D. J. (1977). The effect of petroleum hydrocarbons on the survival and life history of polychaetous annelids. In: Wolfe, D. A. (ed.) Fate and effects of petroleum hydrocarbons in marine organisms and ecosystems. Pergamon Press, New York, p. 168-173

Carr, R. S., Reish, D. J. (1978). Studies on the Mytilus edulis community in Alamitos Bay, California VII. The influence of water-soluble petroleum hydrocarbons on byssal thread formation. Veliger 21: 283-287 
Carr, R. S., Williams, J. W., Saksa, F. I., Buhl, R. L., Neff, J. M (1984). Bioenergetic alterations correlated with growth fecundity, and body burden of cadmium for Mysidopsis bahia during a life-cycle exposure. Environ. Toxicol. Chem. (in press)

Gabbott, P. A., Bayne, B. L. (1973). Biochemical effects of temperature and nutritive stress on Mytilus edulis L. J. mar. biol. Ass. U.K. 53: 269-286

Gilfillan, E. S., Mayo, D. W., Hanson, S., Donovan, D., Jiang, L. C. (1976). Reduction in carbon flux in Mya arenaria caused by a spill or no. 6 fuel oil. Mar, Biol. 37: 115-123

Gilfillan, E. S., Mayo, D. W., Page, D. S., Donovan, D., Hanson, S. (1977). Effects of varying concentrations of petroleum hydrocarbons in sediments on carbon flux in Mya arenaria. In: Vernberg, F. J., Calabrese, A., Thurberg, F P., Vernberg, W. B. (ed.) Physiological responses of marine biota to pollutants. Academic Press, New York, p. 299-314

Heitz, J. R., Lewis, L., Chambers, J., Yarbrought, J. D. (1974). The acute effects of Empire Mix crude oil enzymes in oysters, shrimp and mullet. In: Vernberg, F. J., Vernberg, W. B. (ed.) Pollution and physiology of marine organisms. Academic Press, New York, p. 311-328

Laughlin, R. B., Linden, O. (1983), Oil pollution and Baltic Sea mysids: acute and chronic effects of the water soluble fractions of light fuel oil on the mysid shrimp Neomysis integer. Mar. Ecol. Prog. Ser. 12: 29-41

Laughlin, R. B., Wofford, H. W., Neff, J. M. (1979). Simple potentiometric method for the rapid determination of respiration rates of small aquatic organisms. Aquaculture 16: 77-82

Lehtinen, K. J., Lehtinen, C. (1980). Apparatur for kontinuerlig dosering av vattenlosliga oljekolvaten (in Swedish). Report No. B572 from the Swedish Environmental Research Institute (IVL)

Linden, O. (1975). Acute effects of oil and oil/dispersant mixture on larvae of Baltic herring. Ambio 4: 130-133

Linden, O. (1977). Sublethal effects of oil on mollusc species from the Baltic Sea. Wat. Air Soil Pollut. 8: 305-313

McKenney, C. L., Jr. (1980). Ecophysiological studies on the ontogeny of euryplasticity in the caridean shrimp Palaemonetes pugio (Holthius) and modifications by zinc. $\mathrm{Ph}$. D. dissertation, Texas A \& M University, College Station, Texas

Nelson-Smith, A. (1968). Biological consequences of oil pollution and shore cleaning. In: McCarthy, J. D., Arthus, D. R (ed.) The biological effects of oil pollution on littoral communities. Field Studies Council, London, p. 73-80

Notini, M., Nagell, B., Hagström, A., Grahn, O. (1977). An outdoor model simulating a Baltic Sea littoral ecosystem. Oikos 28: 2-9

O'Sullivan, A. J., Richardson, A. J. (1967). The Torrey Canyon disaster and intertidal marine life. Nature, Lond. 213: $541-542$

Rossi, S. S., Anderson, J. W., Ward, G. S. (1976). Toxicity of water-soluble fractions of four test oils for the polychaetous annelids, Neanthes arenaceodentata and Capitella capitata. Environ. Pollut. 10: 9-18

Rudling, L. (1976). Oil pollution in the Baltic Sea Report No PM783 from the Swedish National Environmental Protection Board

Solorzano, L. (1969). Determination of ammonia in natural waters by the phenolhypochlorite method. Limnol. Oceanogr, 14: 799-801

Stickle, W. B., Jr., Rice, S. D., Villars, C., Metcalf, W. (1984). Bioenergetics and survival of the marine mussel, Mytilus edulis, during long-term exposure to the water-soluble fraction of Cook Inlet crude oil. In: Vernberg, F. J., Calabrese, A., Thurberg, F. P., Vernberg, W. B. (ed.) Physiological effects of pollutant stress. Academic Press, New York (in press)

Vargo, S. L. (1981). The effects of chronic low concentration of No. 2 fuel oil on the physiology of a temperature estuarine zooplankton community in the MERL microcosms. In: Vernberg, F. J., Calabrese, A., Thurberg, F. P., Vernberg, W. B. (ed.) Biological monitoring of marine pollutants. Academic Press, New York, p. 295-322

Widdows, J. (1978). Physiological indices of stress in Mytilus edulis. J. mar. biol. Ass. U.K. 58: 125-142 